\title{
Global E-government Trends, Challenges and Opportunities
}

\author{
Alanoud Alshehri, Somayah Alharbi, Mashael Khayyat, Omar Aboulola \\ Department of Information Systems and Technology, College of Computer Science and Engineering, \\ University of Jeddah, Jeddah, Saudi Arabia
}

\begin{abstract}
E-government is crucial in this era for all countries, either developed or developing. Although it has provided numerous advantages and opportunities, the E-government transformation is still considered a complex process. Considering the available research work and data on e-government surveys by the United Nations, this research has primarily focused on the global complexities of applying E-government along with regional and global E-government leaders. This research has been conducted using a systematic review methodology. According to 2020 surveys, the results are promising to show significant advancement in digital services in various geographic regions, cities, and countries. However, the results showed also that the most common challenges facing governments worldwide are the absence of digital infrastructures, limited resources for adopting the digital government policies, and lack of trust. Hence, governments must build trust with their citizens so that they can participate and avoid any resistance.
\end{abstract}

Keywords - E-government development, implementation challenges, global leaders, digital transformation.

DOI: $10.18421 /$ SAR44-04

https://doi.org/10.18421/SAR44-04

Corresponding author: Mashael Khayyat,

Department of Information Systems and Technology, College of Computer Science and Engineering, University of Jeddah, Jeddah, Saudi Arabia.

Email: Mkhayyat@uj.edu.sa

Received: 24 November 2021.

Revised: 14 December 2021.

Accepted: 20 December 2021.

Published: 27 December 2021.

(C) 2021 Alanoud Alshehri et al; published by UIKTEN. This work is licensed under the CC BY-NC 4.0.

The article is published with Open Access at www.sarjournal.com

\section{Introduction}

The concept of E-government has become a worldwide phenomenon for improving people's lives and making the government processes more flexible and transparent [1]. The advancement in information and communication technologies such as more accessible access to the Internet and electronic devices such as cellular devices have changed government operations and made citizens expect public services to be more efficient and transparent [2]. The advancement in technology has made it necessary for all governments to provide their services online, resulting in a new phenomenon termed E-government [1].

The main objective of the E-government implementation is to reduce the cost, decrease the effort required for providing services, improve the ease of workflow process, and enhance transparency [2]. Thus, it becomes necessary for the government and private organizations to run citizen awareness campaigns about these services and their value [2]. Usually, citizens prefer engaging with highly qualified administration that provides secure, reliable, and sustainable services compared to undefined ones. The implementation of Egovernment certainly guarantees the fulfilment of Egovernment functions by establishing the wellqualified services infrastructure.

This research aims to investigate the status of Egovernment development along with providing information about its implementation, obstacles, and worldwide growth. As well as seeks to answer the following questions to achieve the study objectives:

- What are the major obstacles in the implementation of E-government in developed and developing countries?

- What is the level of today's digital government?

- What is the potential transformation in Egovernment growth for addressing national and local needs? 
The research objectives are as follows:

- Determine the effectiveness of global Egovernment services.

- Identify the current challenges and risks of Egovernment development in developed and developing countries.

- Assess the weaknesses and present an approach to solving them.

The first section introduces the topic, followed by the literature review and then the research methodology. In the third section, we have global trends in E-government in addition to the country's leading E-government implementation. Section four represents the result of E-governments regional challenges and opportunities; section five continues the discussion and conclusion. Finally, future research directions have been presented.

\section{Literature Review}

There are numerous research papers that have the concept of E-government and difficulties faced at the time of its implementation. Apart from that, researchers have also covered the important aspects such as different practices that have been adopted by different countries and how they can be developed, but there are limited researches carried out on the extent of its implementation in the current era.

According to Bertota et al. (2014), E-government is the way for governments to utilize information and communication technologies to provide assistance to their citizens. It acts as a source of connection for bringing citizens and businesses closer.

Furthermore, the contemporary issues commonly faced by the governments is the administration interface such as people-computer interface management, and study of such problems helps to resolve such issues. While according to another research that discusses big data and E-government, big data can play an important role in creating the smart government by creating real-time solutions to challenges in different sectors where it is necessary for governments to provide assistance such as agriculture, transportation, and health sector [3]. However, there are several issues that relate to policymaking, digital asset management, and security that need attention to implement the concept of Egovernment [3]. If this research is taken into consideration, it is evident that security and digital asset management are two main concerns for any government as if people have trust issues, it will ultimately result in the failure of the implementation of E-government. Apart from that, it will also make citizens reluctant to avail themselves of the services provided by the government [3].

In another research which is carried out on Egovernment in the UK and its challenges and complexities, researchers have stated that efforts to deploy the E-government in the country suggest that the majority of local boroughs are lagging behind the national expectations due to numerous reasons such as social and technical issues. According to this research, the lack of awareness, language barrier, and lack of access to the Internet are major social concerns of citizens for availing these services. Additionally, these issues are further compounded by technical difficulties such as the need to integrate business practices and processes in different government sectors so that these services can be provided with ease. Even though developed countries have made significant progress, but still lack behind.

Apart from that, there are other researchers who have also covered the same perspective and described these issues. Hence it can be stated that lack of awareness, trust issue, and security are major concerns and prove to be a hurdle for implementing the concept of E-government. If any government takes some necessary steps to provide awareness and to implement it completely, it will not only be easier for governments to provide these services, but also it will result in efficient service provision.

\section{Leading E-government implementation Countries}

According to the analysis and evaluation of results of the 2020 survey, 14 nations in the most elevated rating class of higher E-Government Development Index (EGDI) group have been tracked down in Table 1. The results showed that the United States continues to lead the E-government growth globally and has a higher EGDI value.

Table 1. Top countries in terms of E-government growth, 2020

\begin{tabular}{|l|c|c|c|}
\hline \multicolumn{1}{|c|}{ Country } & Region & $\begin{array}{c}\text { EGDI } \\
\text { value } \\
-2020\end{array}$ & $\begin{array}{c}\text { EGDI } \\
\text { value } \\
-2018\end{array}$ \\
\hline Denmark & Europe & 0.9758 & 0.915 \\
\hline Republic of Korea & Asia & 0.956 & 0.901 \\
\hline Estonia & Europe & 0.9473 & 0.8486 \\
\hline Finland & Europe & 0.9452 & 0.8815 \\
\hline Australia & Oceania & 0.9432 & 0.9053 \\
\hline Sweden & Europe & 0.9365 & 0.8882 \\
\hline $\begin{array}{l}\text { United Kingdom of } \\
\text { Great } \\
\text { Britain and Northern } \\
\text { Ireland }\end{array}$ & Europe & 0.9358 & 0.8999 \\
\hline New Zealand & Oceania & 0.9339 & 0.8806 \\
\hline $\begin{array}{l}\text { United States of } \\
\text { America }\end{array}$ & Americas & 0.9297 & 0.8769 \\
\hline Netherlands & Europe & 0.9228 & 0.8757 \\
\hline Singapore & Asia & 0.915 & 0.8812 \\
\hline Iceland & Europe & 0.9101 & 0.8316 \\
\hline Norway & Europe & 0.9064 & 0.8557 \\
\hline
\end{tabular}

Source: 2020 United Nations E-Government Survey

In online service provision (OSI), Korea is leading the world, and it is the best EGDI performer in Asia, followed by Singapore and Japan. At the same time, Denmark has the highest EGDI consecutively two times in the world and is also one of the seven North 
European countries and one of the five European Union countries with a higher rating. From 2018 to 2020, the other European Union countries have also improved their result, as in the case of Estonia, which has the highest EGDI, and Finland has also made significant progress. [4]

Through major improvements in the technological infrastructure component (TII), the United Kingdom and Sweden were able to achieve a higher overall EGDI value. The Netherlands is the last member of the European Union in the top-ranking category. All three EGDI subindices improved in the case of Norway and Iceland, both of which are in Northern Europe and have an overall ranking of the thirteenth and twelfth, respectively. The leaders of Oceania, Australia, and New Zealand remain in the top EGDI category and are well ranked inside the top-ranking class. Finally, none of Africa's countries are rated in the top class. [4]

\section{Saudi Arabia E-government's position}

Asia's average EGDI increased in 2020, and it is the second most progressive region for E-government growth (see Table 2.).

Table 2. Asia's countries with the highest EGDI values

\begin{tabular}{|c|c|c|c|c|}
\hline Country & $\begin{array}{l}\text { EGDI } \\
\text { Rank }\end{array}$ & Sub-Region & $\begin{array}{l}\text { EGDI } \\
(2020)\end{array}$ & $\begin{array}{l}\text { EGDI } \\
\text { (2018) }\end{array}$ \\
\hline $\begin{array}{l}\text { Republic } \\
\text { of Korea }\end{array}$ & 2 & Eastern Asia & 0.9560 & 0.901 \\
\hline Singapore & 11 & $\begin{array}{c}\text { South- } \\
\text { Eastern Asia }\end{array}$ & 0.9150 & 0.8812 \\
\hline Japan & 14 & Eastern Asia & 0.8989 & 0.8783 \\
\hline Cyprus & 18 & $\begin{array}{c}\text { Western } \\
\text { Asia }\end{array}$ & 0.8731 & 0.7736 \\
\hline $\begin{array}{l}\text { United } \\
\text { Arab } \\
\text { Emirates }\end{array}$ & 21 & $\begin{array}{l}\text { Western } \\
\text { Asia }\end{array}$ & 0.8555 & 0.8295 \\
\hline Kazakhstan & 29 & Central Asia & 0.8375 & 0.7597 \\
\hline Israel & 30 & $\begin{array}{c}\text { Western } \\
\text { Asia }\end{array}$ & 0.8361 & 0.7998 \\
\hline Bahrain & 38 & $\begin{array}{c}\text { Western } \\
\text { Asia }\end{array}$ & 0.8213 & 0.8116 \\
\hline $\begin{array}{l}\text { Saudi } \\
\text { Arabia* }\end{array}$ & 43 & $\begin{array}{c}\text { Western } \\
\text { Asia }\end{array}$ & 0.7991 & 0.7119 \\
\hline China* & 45 & Eastern Asia & 0.7948 & 0.6811 \\
\hline Kuwait* & 46 & $\begin{array}{c}\text { Western } \\
\text { Asia } \\
\end{array}$ & 0.7913 & 0.7388 \\
\hline Malaysia* & 47 & $\begin{array}{c}\text { South- } \\
\text { Eastern Asia }\end{array}$ & 0.7892 & 0.7174 \\
\hline Oman* & 50 & $\begin{array}{c}\text { Western } \\
\text { Asia }\end{array}$ & 0.7749 & 0.6846 \\
\hline Turkey* & 53 & $\begin{array}{c}\text { Western } \\
\text { Asia }\end{array}$ & 0.7718 & 0.7112 \\
\hline Thailand* & 57 & $\begin{array}{c}\text { South- } \\
\text { Eastern Asia }\end{array}$ & 0.7565 & 0.6543 \\
\hline
\end{tabular}

* Countries that shifted from a moderate to a very high EGDI category in 2020

Source: 2020 United Nations E-Government Survey
Asia has specifically worked on the infrastructure, and its performance has also been driven by the development of infrastructure. The KSA is one of the seven Asian nations that have high EGDI without precedent in 2020, along with other countries such as Kuwait, Turkey, China, Thailand, Oman, and Malaysia. [4]

\section{Methodology}

This research has been conducted using a systematic review. In order to examine the current level of E-government implementation improvements, difficulties, and openings globally, the authors in this research have followed two principal research steps. First, the risks, challenges, strategies, and initiatives of E-government in both scenarios, i.e., the turn of events and present-day nations, were distinguished from a detailed review of literature that directly relates to E-government adoption worldwide. Selecting the papers and articles was based on relevance to the overall status of the Egovernment in a specific country or region. These kinds of exact papers revealed deep insights into the stereotype of the E-government. That leads us to realize how the income, education, digital divide, country size, and cultures involved format the Egovernment. We had considered nine countries from different regions to analyze them and present the interesting risks, challenges, strategies, and initiatives of each. As a result, we highlighted and discussed the most common challenges that obstruct E-government implementation and adoption worldwide despite the variation and diversity.

Secondly, the E-government patterns and progress are characterized by the provided results of the survey of 2020 conducted by the United Nations [5]. The results of these surveys have provided significant information and act as the leading reference for E-government implementation and as a tool for policymakers over the last decade. It is the only worldwide report that has provided the evaluation of E-government improvement status for all members of the United Nations. Additionally, it also serves as a benchmark and a tool for all members to learn from one another and to understand the challenges, strengths, and opportunities in Egovernment, and shape their strategies to provide and enhance services to their citizens.

We studied the analytical part of the survey and considered the logical piece dependent on a writing audit and an examination of the survey's information. The common challenges of E-government found in the survey were listed and were compared with the literature reviews found for the situation investigation. There were a few cycles all through the exploration as each case presented new likely advantages. 


\section{Data Analysis}

As per Table 3., we have created the following chart (see Figure 1.) that illustrates the E-government growth rate in the last six years. From the chart, it is realized that the Kingdom of Bahrain is the first leader in the Gulf Cooperation Council (GCC), with steady performance despite the progress in recent years made by the United Arab Emirates. The UAE is the current leader for E-government in the Gulf Cooperation Council, and in terms of the ICT infrastructure, the UAE is one of the most advanced countries in the GCC region [6], [7], [5].

Table 3. GCC ranking in 2016, 2018, and 2020

\begin{tabular}{|c|c|c|c|c|c|}
\hline \multicolumn{2}{|c|}{2016 Ranking } & \multicolumn{2}{|c|}{ 2018 Ranking } & \multicolumn{2}{c|}{ 2020 Ranking } \\
\hline Bahrain & 24 & UAE & 21 & UAE & 21 \\
\hline UAE & 29 & Bahrain & 26 & Bahrain & 38 \\
\hline Kuwait & 40 & Kuwait & 48 & $\begin{array}{c}\text { Saudi } \\
\text { Arabia }\end{array}$ & 43 \\
\hline $\begin{array}{c}\text { Saudi } \\
\text { Arabia }\end{array}$ & 44 & Qatar & 51 & Kuwait & 46 \\
\hline Qatar & 48 & $\begin{array}{c}\text { Saudi } \\
\text { Arabia }\end{array}$ & 52 & Oman & 50 \\
\hline Oman & 66 & Oman & 63 & Qatar & 66 \\
\hline
\end{tabular}

Source: United Nations E-Government Survey in 2016, 2018, and 2020

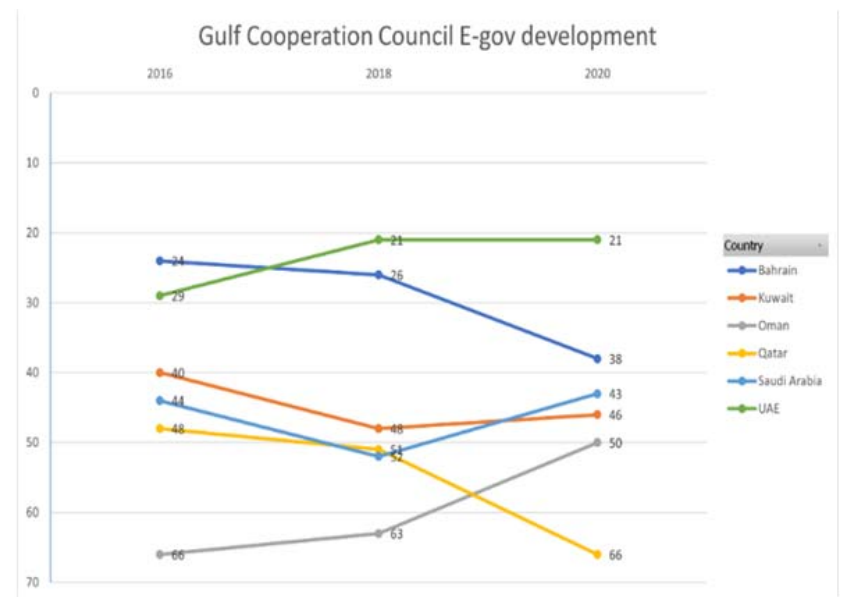

Figure 1. E-government development in GCC

The UAE government decided to take ownership of the identity process and provide its citizens with secure, exclusive, and tamper-proof digital identities. This form of identity enhances security, gains higher levels of confidence and trust, and encourages participation. This initiative helps the UAE government to obtain citizen trust, which is the key to improving E-government utilization. The state of Kuwait and the Kingdom of Saudi Arabia have similar progress in the last five years. However, recently Saudi Arabia achieved more in the Egovernment sector and paid more attention to the importance of the E-government process. As shown in Figure 1., it is realized that the major positive performance in the E-government in the Gulf Cooperation Council is the Sultanate of Oman, it moved from the 66th rank to the 50th rank within about five years, while Qatar retreated from the 48th rank to the 66th rank [6], [7] [5].

\section{Results and Discussion}

This section presents the result of the most common challenges facing governments worldwide. We had discovered it as a result of our research and analysis. Governments make the best effort to communicate with citizens and provide them with online services. However, there are many challenges in E-government development that are considered as global challenges, and the governments need to pay attention to these challenges to enhance their services.

The following challenges have ranked as per their impact and popularity:

\section{E-government Services Trust}

Establishing E-government, requires a high level of trust as it is the most critical factor in the implementation of E-government projects [8]. It is the basis of how people interact and form positive relationships with each other [1]. People would not engage in the E-government process if they felt a lack of trust.

Trust in E-government requires trust in the government. Improving accountability and transparency, which are a priority to improve citizens' perceptions of government [8]. Selecting the right business partner in the E-government sector is a crucial factor for users' trust agreement and to have the best possible online government transaction outcomes along with building a government-citizen partnership.

For instance, citizens' trust in government decisions has been damaged after the financial crisis and the bailout of Cyprus in 2013 that impacted the E-government adaption and made it harder for the government to persuade citizens to utilize the Egovernment services [1] [9].

As trust issue can halt citizens from availing Egovernment services. The increased trust would assist the governments in dealing with other challenges such as "change resistance," privacy, and security concerns [2].

\section{Information Security}

Information security is ensured using a variety of systems that adhere to the security policy. Information privacy is protected by software 
mechanisms that ensure that only the owner of the information or official entities with authority obtain or access the information.

The implementation of E-government is heavily reliant on two major factors: trust and security. Governments should start building E-networks with privacy and confidentiality protections in place, ensuring the protection of personal and financial data collected and increasing people's trust [2] [8].

Lack of security and privacy are considered key concerns that must be resolved in E-government to fulfill users' standards. Any assurances from the government on matters of information security and privacy would be insufficient unless these technical challenges are resolved and processes become more transparent [1]. Users of E-government systems will decrease if citizens have trust issues, and the system faces security issues, cyber-attacks, and interception of important information.

People in Ghana do not find online payment secure enough due to connection failures, sluggish Internet, frequent equipment breakdowns, and a lack of confidence in payment security, so they are reluctant to provide sensitive personal details that make the Egovernment service less efficient [10].

\section{ICTs Infrastructure}

ICT infrastructure is a crucial challenge in Egovernment. Improving citizens' confidence in government through a stronger and more advanced ICT infrastructure is crucial to growing their ability to use online services [8].

For instance, in 2007, the Qatar government provided free Wi-Fi access in public parks for enhancing the usability of E-government services and to increase user participation in a great initiative and respected step to reduce the impact of infrastructure unavailability [8]. The Indian government developed a Common Service Center (CSC) in rural areas to provide e-government services to people in a single physical location, resulting in increasing Egovernment services use, improved citizen services, and lower travel costs [2].

In general, all infrastructure aspects are considered as factors that can either support or impede the smooth implementation of E-projects. Residents can be hesitant to utilize E-government services due to the privation of necessary infrastructures such as electricity and basic amenities [1].

\section{Digital Divide}

The concept of the digital divide refers to unequal access of ICT to citizens and the lack of knowledge and skills to use it. The lack of skills and variance in access is one of the main concerns for different governments as it poses a major challenge [9]. With an increase of availability of different E-government services, it has also given birth to debate that why some citizens are reluctant to use E-government services, and some are readily availing it.

Early adopters of any technical revolution have a few things in common: they're young, educated, and have higher incomes [9]. People having higher education and income are more inclined towards using these services provided by the government and engaging effectively.

Governments must bridge the digital divide such that all people access the same quality of government information and services by introducing technical advances in rural areas so that people from rural areas can also avail these services readily.

\section{Conclusion}

E-government is crucial in this era for all countries, either developed or developing. It is necessary to have an E-government to facilitate people and to enhance the effectiveness of government, but there are some concerns in some developing countries that require urgent attention to face their challenges. The most common challenges facing governments worldwide are the absence of digital infrastructures, restricted resources for adopting digital government policies, and lack of trust. The lack of trust in government initiatives hampers the progress of implementation of Egovernment. Hence, governments must build trust with their citizens so that they can participate in the E-government process and avoid any resentence. In conclusion, E-government has progressed to the point of maturity in some developed countries but going digital is still comparatively new for some developing countries.

\section{Future Research Directions}

In the future, we suggest extending the methodology to cover more than 40 papers from different continents and regions to elaborate more on the insight of the E-government status across the world and the common challenges per area. As well as we believe adding qualitative criteria to categorize the E-government status will enhance the topic analysis. Additionally, discussing the success factors and highlighting the unique initiatives in the Egovernment also will add value to the research.

Finally, future research can tackle areas such as:

- How the countries worldwide deal and manage the most common challenges we have mentioned in this research.

- The current status of the E-government in Saudi Arabia and its most common challenges and how this can be managed.

- The E-government growth factors in Saudi Arabia and the United Arab Emirates, and Oman. 


\section{References}

[1]. Glyptis, L., Christofi, M., Vrontis, D., Del Giudice, M., Dimitriou, S., \& Michael, P. (2020). EGovernment implementation challenges in small countries: The project manager's perspective. Technological Forecasting and Social Change, 152, 119880.

[2]. Sharma, S. K., Metri, B., Dwivedi, Y. K., \& Rana, N. P. (2021). Challenges common service centers (CSCs) face in delivering e-government services in rural India. Government Information Quarterly, 38(2), 101573.

[3]. Bertot, J. C., Gorham, U., Jaeger, P. T., Sarin, L. C., \& Choi, H. (2014). Big data, open government and egovernment: Issues, policies and recommendations. Information polity, 19(1, 2), 5-16.

[4]. Desa, U. N. (2016). Transforming our world: The 2030 agenda for sustainable development. . [Online]. Available: https://sdgs.un.org/2030agenda. [Accessed 28 February 2021].

[5]. Zhenmin, L. (2020). United Nations E-Government survey 2020.
[6]. Undesa, U. (2016). United Nations e-government survey 2016: E-government in support of sustainable development. United Nations, New York (2016).

[7]. des Nations Unies, O. (2018). United Nations EGovernment Survey 2018: Gearing E-Government to support transformation towards sustainable and resilient societies. New York, NY: United Nations.

[8]. Alkhusaili, M. M., \& Aljazzaf, Z. M. The Evolution of E-government Project in GCC Countries. Proceedings of the International Conference on Industrial Engineering \& Operations Management, p. 13, 2020.

[9]. Pérez-Morote, R., Pontones-Rosa, C., \& NúñezChicharro, M. (2020). The effects of e-government evaluation, trust and the digital divide in the levels of e-government use in European countries. Technological Forecasting and Social Change, 154, 119973.

[10]. Quaye, J. D., \& Sneiders, E. (2020, April). Egovernment adoption: The role of perception of digital technology in the public service of Ghana. In 2020 Seventh International Conference on eDemocracy \& eGovernment (ICEDEG) (pp. 225-230). IEEE. 